\title{
Relationship between vacA Types and Development of Gastroduodenal Diseases
}

\author{
Tran Thi Huyen Trang ${ }^{1,2}$, Tran Thanh Binh ${ }^{1,3}$ and Yoshio Yamaoka ${ }^{1,4, *}$ \\ 1 Department of Environmental and Preventive Medicine, Oita University Faculty of Medicine, 1-1 Idaigaoka, \\ Hasama-Machi, Yufu-City, Oita 879-5593, Japan; huyentrang110@yahoo.com (T.T.H.T.); \\ binh79@oita-u.ac.jp (T.T.B.) \\ 2 Department of Molecular Biology, 108 Hospital, Hanoi, Vietnam \\ 3 Department of Endoscopy, Cho Ray Hospital, Ho Chi Minh, Vietnam \\ 4 Department of Medicine-Gastroenterology, Michael E. DeBakey Veterans Affairs Medical Center and Baylor \\ College of Medicine, Houston, TX 77030, USA \\ * Correspondence: yyamaoka@oita-u.ac.jp; Tel.: +81-97-586-5740; Fax: +81-97-586-5749
}

Academic Editor: Timothy L. Cover

Received: 15 March 2016; Accepted: 31 May 2016; Published: 9 June 2016

Abstract: The Helicobacter pylori vacuolating cytotoxin (VacA) is a secreted pore-forming toxin and
a major virulence factor in the pathogenesis of H. pylori infection. While VacA is present in almost all
strains, only some forms are toxigenic and pathogenic. While vacA and its genotypes are considered
as markers of H. pylori-related diseases or disorders, the pathophysiological mechanisms of VacA and
its genotypes remain controversial. This review outlines key findings of publications regarding vacA
with emphasis on the relationship between vacA genotypes and the development of human disease.

Keywords: VacA genotypes; vacuolation; prolonged Helicobacter pylori infection; H. pylori-mediated diseases

\section{VacA and Allelic Diversity of $v a c A$}

Helicobacter pylori (H. pylori) infection has been implicated in a range of disorders of the upper gastrointestinal tract and associated organs. However, virulence mechanisms responsible for $H$. pylori persistence and clinical outcomes remain controversial. Ongoing efforts to decipher the pathophysiology of $H$. pylori infection have illuminated crucially important contributions of a number of bacterial factors in H. pylori pathogenesis. The vacuolating cytotoxin (VacA) has been identified as one of the most important of these virulence factors. As an intracellular-acting protein exotoxin, VacA affects multiple cellular pathways in different host cell types and induces host cell vacuolation and cell death. Furthermore, specific vacA genotypes have also been reported to be useful for predicting risk of different clinical outcomes [1-3].

Although nearly all strains isolated from humans possess the vacA gene, the capacity to induce cell vacuolization differs significantly from strain to strain [4,5]. Previously, vacuolating cytotoxin phenotypes were determined based on the levels of vacA transcription or by the efficiency of VacA secretion [6]. However, subsequent studies have demonstrated that phenotypes are modulated by genetic variation within the $v a c A$ gene. The three high sequence diversity regions of the vacA closely associated with vacuolating activity and with clinical outcomes include the signal (s)-, intermediate (i)-, and middle (m)- region [5,7-11]. The vacA s- and the m-regions are the two main polymorphic regions and have been well-characterized as markers of $H$. pylori's virulence and risk of progression to serious diseases $[5,7,12-14]$. The first polymorphic region of vacA (s-region) includes both signal peptides and is defined as a part of the apparatus to transport the mature virulent $88 \mathrm{kDa}$ VacA toxin and the amino-terminal residues of p33 which is predicted as a highly hydrophobic domain of VacA. In contrast, the m-region encodes part of the carboxyl-terminal p55 subunit which has an important 
role in mediating VacA binding to host cells [15]. The i-region is the third polymorphic determinant and is located in the carboxyl-terminal half of $\mathrm{p} 33$ between the s-region and m-region [10]. The i-region appears to interact with the $\mathrm{s}$ and $\mathrm{m}$ regions and has been described as the determinant of VacA toxicity. Furthermore, the i-region has been suggested to be a better predictor of disease severity than either the s- or m-regions $[10,16]$. Based on the amino acid sequence differences within these regions, two or more primary variants have been described for each region: $\mathrm{s} 1$ and $\mathrm{s} 2$ for the signal region; i1, i2 and i 3 for the intermediate region; and $\mathrm{m} 1$ and $\mathrm{m} 2$ for the middle region. Furthermore, the $\mathrm{s} 1$ and $\mathrm{m} 1$ genotypes have been further classified into three subtypes $\mathrm{s} 1 \mathrm{a}, \mathrm{s} 1 \mathrm{~b}, \mathrm{~s} 1 \mathrm{c}$ and $\mathrm{m} 1 \mathrm{a}, \mathrm{m} 1 \mathrm{~b}$, $\mathrm{m} 1 \mathrm{c}$, respectively $[5,9,11,17-19]$. Recently, two additional regions of variation were found in vacA: the deletion (d)-region, located between the $\mathrm{i}$ - and the $\mathrm{m}$-region exhibiting either $\mathrm{d} 1$ genotype without the 69-81 base pair (bp) deletion or $\mathrm{d} 2$ genotype with the deletion; and c-region [20,21]. The last includes a deletion of $15 \mathrm{bp}$ located at the $3^{\prime}$-end region sequences of the vac $A$ and divided into $c 1$ (with deletion) and c1 (without deletion) (Figure 1).

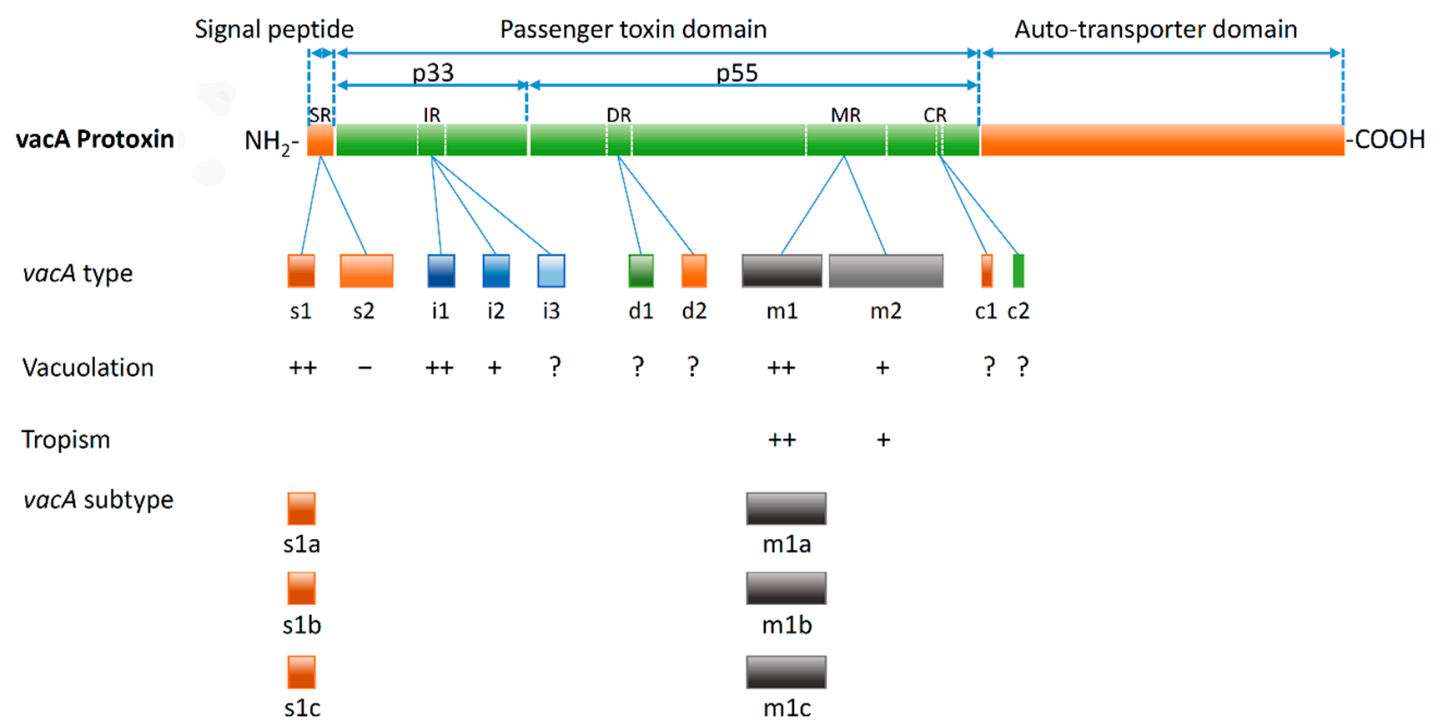

Figure 1. Sequence diversity regions of the vacA closely associated with vacuolating activity of $H$. pylori and clinical outcomes are localized to the signal region (SR); the intermediate region (IR) on p33 domain; the d-region (DR), middle region (MR) and c-region (CR) on p55 domain. The different types of these regions are associated with differences in vacuolation, specificity and clinical outcome. The s1, m1, i1 type have been classified as fully active VacA and are associated with a higher risk of development of GC than the s2, m2, or i2. In contrast to the s1 type, the s2 forms of VacA consistently lack detectable vacuolation activity in most in vitro assays. In comparison to the $\mathrm{m} 1 / \mathrm{i} 1$ types, the $\mathrm{m} 2 / \mathrm{i} 2$ types are considerably less active and are virtually nontoxic. The function of the i3 remains undefined. The d-region has been considered to be related with VacA binding to the host gastric cells and vacuolating activity, however, compelling evidence to support this is still lacking. The function of the c-region remains a mystery; however, the $\mathrm{c} 1$ genotype has been strongly associated with the risk of GC. The s1 and $\mathrm{m} 1$ genotype have been further classified into the three subtypes s1a, s1b, s1c and m1a, $\mathrm{m} 1 \mathrm{~b}, \mathrm{~m} 1 \mathrm{c}$, respectively.

\section{The Association of $v a c A$ Genotypes and Cytotoxin}

The most distinct effect of VacA is vacuolation of cells. After VacA internalization, internal membranous vesicles accumulate. Anion-selective channels are created in the membrane of these vesicles which facilitate the transport of chloride ions. VacA induces the accumulation of membrane permeable weak bases and finally results in osmotic swelling and vacuolation [22,23]. Even though the physiological role of vacuolation is still unclear, vacuolation occurring during $H$. pylori infection is 
thought to disrupt protein trafficking pathways to and from the plasma membrane and consequently affect a number of cellular functions [24-26].

vacA genotypes rather than simply the presence or absence of VacA have been identified as critical determinants of pathogenesis, Recent studies have explored the contributions of different vacA genotypes in relation to vacuolating activity as well as to $H$. pylori pathogenesis. vacA s1 encodes a protein which fully exhibits vacuolating activity. vacA s2 encodes a protein with a different signal peptide cleavage site, resulting in a 12-amino-acid amino-terminal extension that inhibits vacuolation [27]. Differences in the cell-binding properties of $\mathrm{m} 1$ and $\mathrm{m} 2$ VacA proteins have also been recognized. For example, the protein encoded by vac $A \mathrm{~m} 1$ causes vacuolation in a wider range of cells than the m2-encoded protein $[5,12,19,28]$. Many studies have reported the genotype of vacA i-region is a marker of disease outcome; however, there has been relatively few studies comparing the activities of the proteins encoded by different types of i-region. vac $A$ i1 shows the strongest vacuolating activity on mammalian cells and is thought to cause significantly greater gastric mucosal inflammation compared to infection with i2 containing strains $[10,16]$. Being phylogenetically closer to the i2 genotype, the i3 genotype is non-vacuolating and has rarely been found [11].

The combination of the vacA s-, m-, $\mathrm{i}-$, region genotypes among $H$. pylori strains provides better differentiation of vacuolating activity between strains and clinical outcomes. Variations in the s- and $\mathrm{m}$-regions gives rise to four different $H$. pylori genotypes; $\mathrm{s} 1 \mathrm{~m} 1, \mathrm{~s} 1 \mathrm{~m} 2, \mathrm{~s} 2 \mathrm{~m} 1$ and $\mathrm{s} 2 \mathrm{~m} 2$ with different abilities to induce the formation of acidic vacuoles in infected cells. In general, s1m 1 strains produce a large amount of toxin and cause the greatest vacuolization of epithelial cells. In contrast, s1m2 strains may or may not induce cell vacuolation depending on the cell line; most $\mathrm{s} 2 \mathrm{~m} 2$ strains produce little or no cytotoxin. s2m1 strains are rare and non-vacuolating $[6,10,18,29,30]$. All s1m1i1 strains are vacuolating and all s $2 \mathrm{~m} 2 \mathrm{i} 2$ are non-vacuolating. $\mathrm{s} 1 \mathrm{~m} 2$ strains containing the i1 genotype induce cell induce cellular vacuolation while those containing the i2 genotype do not. Thus, s1m1i1 and $\mathrm{s} 1 \mathrm{~m} 2 \mathrm{i} 1 \mathrm{strains}$ are more virulent and more likely associated with gastric cancer (GC) than the s2m2i2 and $\mathrm{s} 1 \mathrm{~m} 2 \mathrm{i} 2$ strains $[1,10,31]$.

Although the d1- and c1- genotype have been considered as biomarkers of a strong risk of GC, the contribution of the d- and c-region and their genotypes to cellular vacuolation is as yet undefined. Considering genotypes of the $\mathrm{d}$ - and c-region in combination with genotypes of other variant regions, $\mathrm{d} 1 / \mathrm{c} 1$ strains are almost exclusively associated with types producing vacuolating cytotoxin (s1/m1/i1) and d2/c2 with non-vacuolating types (s2/m2/i2) [20,21]. Further studies will be required to systematically analyze the role of these regions and their genotypes in the induction of vacuolation.

\section{The Relationship between vacA Polymorphism and H. pylori Persistence}

After colonizing host cells, the bacteria produce toxins which can cause a broad spectrum of cellular alterations. The toxin has also been hypothesized to enable bacterial colonization by creating extensive remodeling of host cells to provide a more suitable colonization niche. Thus, toxin-producing bacteria may have a selective advantage for colonization compared with strains that do not produce a particular toxin [23]. Since all H. pylori strains possess vacA and genotype of the vacA is significantly associated with the risk of developing a clinical diseases, the secreted pore-forming toxin VacA is thought to facilitate $H$. pylori persistence. It has been proposed that VacA enhances the ability of H. pylori to colonize the mouse stomach [32]. However, H. pylori strains with vacA type s1 and s2 have both been able to colonize the mouse stomach without a significant difference [33]. This has been further clarified by experiments in which it was shown that the expression of the s1i1 or s1i2 genotypes significantly reduced both the proportion of successful infections and gastric colonization density in successfully infected mice compared with the expression of the s2i2 genotype [34]. Other data suggested a correlation between vacA genotype with $H$. pylori persistence and antimicrobial susceptibility. For example, most $H$. pylori isolates found to be resistant to all tested antibiotics were positive for the vacA s1a m1 genotype [35]. The contribution of the vacA genotype to persistent infection 
has also been related to VacA associated inhibition of the proliferation and immune response of $\mathrm{T}$ cells [36]. During H. pylori infection, T cells are hypo-responsive thought to be related to the activity of transforming growth factor $\beta$ (TGF- $\beta$ ) exerting a suppressive effect on T cells. The expression levels of mucosal TGF- $\beta 1$ have been demonstrated to be dependent on the vac $A$ genotypes, with a positive correlation being reported between secreted $v a c A \mathrm{~s} 1$ or $\mathrm{s} 1 \mathrm{~m} 1$ types and increased mucosal TGF- $\beta 1$ mRNA levels. Thus, the vacA s1m1 genotypes have been thought to contribute to persistent infection with $H$. pylori. On the other hand, the role of the active genotype $\mathrm{s} 1$ in $H$. pylori persistence has been suggested to be related to preserving the niche for $H$. pylori by inducing attenuation of the tumor necrosis factor-related apoptosis-inducing ligand (TRAIL) system [37]. The down-regulation of the TRAIL system, in the context of an H. pylori infection, may limit apoptosis of gastric epithelial cells and destruction of tissues necessary for $H$. pylori to maintain its niche and survival in gastric epithelial cells. The down-regulation of the TRAIL system has been shown to be reduced in patients infected with $H$. pylori carrying the vacA s1 compared to those carrying the vacA s2. Prolonged $H$. pylori infection has been presumed to lead to saturation of cellular repair capabilities, the loss of glands, resulting in atrophic gastritis, followed by the development of intestinal metaplasia and dysplasia [38-40]. Thus, by facilitating H. pylori consistent colonization in the host cells, active VacA producing strains may contribute to $H$. pylori disease pathogenesis.

\section{Role of the vacA Genotype in Gastroduodenal Diseases}

H. pylori infection increase apoptosis in the gastric mucosa which may contribute to gastric diseases including peptic ulcer diseases (PUD) and GC [15,41-44]. In an effort to characterize the role of different vacA genotypes in $H$. pylori-associated gastroduodenal diseases, the effect of the $v a c A$ genotypes on gastric epithelial cells has been increasingly investigated. Numerous studies have provided evidence for a stronger association of disease outcomes in individuals infected with $H$. pylori strains possessing active $v a c A$ genotypes such as $\mathrm{s} 1, \mathrm{~m} 1, \mathrm{i} 1, \mathrm{~d} 1$ than that with less or non-active $v a c A$ types $[5,14,15,18]$. The prevalence of these genotypes in patients with PUD and GC is significantly greater than among those with gastritis alone $[2,14,45]$. The differential geographic distribution of these genotypes has also suggested the prevalence of vacA types was higher in areas where the incidence of GC is high compared to areas with a low incidence of GC [46].

An association of $v a c A$ s1 strains and enhanced gastric mucosal inflammation was found in very early studies evaluating the contribution of the vac $A$ genotype in gastroduodenal diseases $[30,47,48]$. The $v a c A$ s1 allele was specified to be correlated with extensive chronic inflammation independently of the $\operatorname{cag} A$ status, possibly through its enhanced ability to produce the vacuolating cytotoxin [48]. The vacA s1 genotype has been associated with the higher levels of interleukin (IL)-8 in the gastric mucosa, chronic inflammation, neutrophil activity, epithelial damage; and with atrophy and intestinal metaplasia rather than the s2 genotype $[16,39,49,50]$. Thus, strains harboring the s1 allele have been considered to be associated with an increased risk of gastric carcinoma than infection with s2 allele containing strains.

vacA $\mathrm{m} 1$ strains have also been associated with gastric diseases and GC compared to $\mathrm{m} 2$ strains. The $\mathrm{m} 1$ genotype has proven to be a better marker than cag $A$ status or vacA s1 genotype for describing the difference of the incidence of GC among East Asian countries where nearly all strains are East Asian types $\operatorname{cag} A$ and vacA s1 [46]. However, some studies have indicated that vacA m-region typing alone is insufficient to distinguish gastroduodenal diseases or identify an increased incidence of GC [49,51]. When m-region genotypes are combined with other vacA genotypes or other virulent factors such as $\operatorname{cag} A$, the contributions of the $v a c A$ genotypes to lesion progression of infected patients are more evident [52,53]. The prevalence of $v a c A$ s1m1 and s1m2 genotypes differ among intestinal GC (IGC) and diffuse GC (DGC) suggesting that these genotypes may play different roles in the pathogenesis of IGC and diffuse DGC [54]. The s1m1 genotype has been found more frequently in children with ulcers, whereas the $\mathrm{s} 2 / \mathrm{m} 2$ genotype has been more frequent in patients with gastritis and gastroesophageal reflux disease (GERD) [55]. cagA-positive strains also correlated with severe histopathological damage 
and CagA is most commonly associated with the vacA s1 genotype, particularly in patients with PUD or GC [56]. Additionally, the $c a g A+v a c A$ s1 genotye is present in patients with high expression of tumor necrosis factor receptor-associated factor 1 (TRAF1), tumor necrosis factor receptor superfamily member 9 (4-1BB), or B-cell lymphoma-extra-large (Bcl-xl) [57]. The expression of TRAF1, and Bcl-xl in human gastric epithelial cells is significantly upregulated in intestinal metaplasia and gastric carcinoma patients whereas in atrophic gastritis there is low expression of these factors. Overall, it seems likely that $\operatorname{cag} A+/$ vacA s1m1 strains upregulate TRAF1 activation, which triggers 4-4BB mediated Bcl-xL activation, thereby exerting an antiapoptotic effect and contributing to the pathogenesis of GC [57]. Interestingly, one study reported a trend for more virulent $c a g A+/ v a c A \operatorname{s} 1 \mathrm{~m} 1$ strains to be present in younger individuals [49], suggesting that the virulence of the infecting strain in early life may determine outcome.

The contribution of genotypes of i-region to gastric diseases has been varied among epidemiology studies [10,16,58,59]. However, most studies confirm tht vacAi genotypes are better predictors of risk of GC or duodenal ulcer than other vacA alleles, cag $A$ status, or the size of the $\operatorname{cag} A 3^{\prime}$ variable repeat region $[2,60,61]$. The strong correlation between the vacA i1 strains and PUD has been recently highlighted [21], and no significant correlation was found between genotypes of s-, m-, d- or c-region, whether independently or in combination and PUD as only the i1 type was linked to an increased risk of PUD [21]. The authors suggested that the carriage of both the i1 type and cag $A$ further increased the risk of PUD in an Iranian population. The ability of the vacAi region to identify patients at higher risk of GC development may be an increased capacity to inhibit activation of nuclear factor of activated $\mathrm{T}$ cells (NFAT) and suppress IL-2 production [62]. A comparison of the ability of the i1 and i2 genotypes to cause functional alterations in Jurkat cells did not reveal differences in the capacity of the i1 and i2 forms in causing vacuolation of RK13 cells; however, i2 forms bound to Jurkat cells less avidly than the i1 forms; i2 forms had a diminished capacity to inhibit the activation of NFAT and suppress IL-2 production compared to the $\mathrm{i} 1$ form. Regarding the combination of 3 vacA regions (s, $\mathrm{m}, \mathrm{i}$ ), the authors found that only naturally occurring $\mathrm{s} 1 \mathrm{~m} 2$ strains varied in i-types with $\mathrm{s} 1 \mathrm{~m} 1$ and $\mathrm{s} 2 \mathrm{~m} 2$ strains were exclusively i1 and i2, respectively.

Even though knowledge of the structure-function relationships of the vacA d region is limited, $v a c A \mathrm{~d} 1$ strains have been proposed as a new determinant of GC risk and for the potential for atrophy compared to the s-, m-, and i-regions [20,63]. Moreover, s1 strains with the d1 genotype were also considered as risk biomarkers in areas of high GC incidence in Iran [64]. Although the biologic role of the c-region in vacuole-creating activities is yet to be understood, the vacA c1 type has been strongly associated with the risk of GC [21]. Furthermore, the combination between the c1 type with vacA-m1, -i1, - $\mathrm{d} 1$ and $\operatorname{cag} A+$ showed a further increase in susceptibility to GC; the combination of $\mathrm{c} 1 / \mathrm{i} 1$ type showed the highest risk of GC.

The vacA genotypes have been demonstrated to be better determinants of the severity of gastric damage compared to the bacterial load. Winter et al. compared vacA genotypes associated-gastric damage in infected-humans and -mice [34] and, as discussed above, compared with the less-active vacA $\mathrm{s} 2 \mathrm{i} 2$ strains, strains producing the s1i1 and the s1i2 showed reduced colonization rates and bacterial densities. However, no significant correlation between colonization density and gastric pathology was observed. Despite colonizing poorly, the s1i1 strains consistently induced more severe and extensive inflammation and spasmolytic polypeptide expressing metaplasia (SPEM) than the s2i2 strains. The finding supported the hypothesis that the induction of inflammation and severe gastroduodenal diseases more related to VacA expression than bacterial density. This finding is in agreement with previous study which showed $H$. pylori genotype is more relevant than bacterial density for induction of oxidative DNA damage involved in gastric carcinogenesis [65]. In that study, density of $H$. pylori was not associated with the level of oxidative DNA damage whereas the more-virulent s1 and $\mathrm{m} 1$ strains were associated with higher levels of oxidative DNA damage than the s2 and the $\mathrm{m} 2$ containing strains, respectively. 


\section{Role of vacA Genotype in Extragastroduodenal Diseases}

H. pylori-mediated diseases from outside of the gastrointestinal track such as disorder in lung or heart have attracted the attention of researchers. H. pylori infection was associated with reduced lung function that is most likely due to the effect of the bacterium on lung growth earlier in life [66]. H. pylori infection has also been associated with systemic inflammation and increased risk of cardiovascular mortality in patients with chronic obstructive pulmonary disease (COPD) [66]. Nevertheless, the attribution of $H$. pylori virulence including the vacA genotypes to development of these diseases remains unclear. To test the importance of $H$. pylori presence in the pathophysiology of upper respiratory diseases in children, a study conducted on children undergoing surgery for adenotonsillar hypertrophy reported that $98 \%$ of the sample was positive for $H$. pylori with predominance of the s1bm2 genotype [67]. Recently, a study demonstrated for the first time that VacA was present in human lung tissues and was more prevalent in lungs of patients with collagen vascular disease-associated interstitial pneumonia than in those of patients with idiopathic pulmonary fibrosis, nonspecific interstitial pneumonia and cryptogenic organizing pneumonia [68]. The findings of the study suggested that induction of IL-8 and IL-6 in airway epithelial cells had a specific reaction against VacA stimulation. Consistent with this finding, another study on the specific relationship between smoking and bacterial load has noted the evidence of the association of the vacA i1 genotype with active-smoking [69]. According to a report of the Surgeon General, the cardiovascular risks were reported to be attributable to active-smoking. Therefore, the correlation of the vacA genotypes in development of diseases in $H$. pylori infected smokers needs to be considered in further study. These correlations remain speculative and it is still unclear whether their presence is restricted to H. pylori.

\section{Conclusions}

H. pylori-associated clinical outcomes relate in part to the genetic diversity among clinical H. pylori isolates. Although all H. pylori strains possess $v a c A$, the secretion and toxicity of VacA are dissimilar among strains. These differences correlate to $v a c A$ polymorphisms. A number of recent studies have demonstrated clinical and biological differences between strains containing different vacA polymorphisms. Detailed studies of the biological activities and clinical associations related to different $v a c A$ genotypes are required for a deeper understanding of their role in $H$. pylori-mediated diseases and for the development of novel strategies to counter their effects.

Acknowledgments: We sincerely apologize to all authors whose important work is not cited in this review, due to page limitations. This report was based on work supported in part by grants from the National Institutes of Health (DK62813) (Yoshio Yamaoka) and Grants-in-Aid for Scientific Research from the Ministry of Education, Culture, Sports, Science and Technology (MEXT) of Japan (25293104, 26640114 and 15H02657) (Yoshio Yamaoka).

Conflicts of Interest: The authors have no competing interests.

\section{References}

1. Ferreira, R.M.; Machado, J.C.; Letley, D.; Atherton, J.C.; Pardo, M.L.; Gonzalez, C.A.; Carneiro, F.; Figueiredo, C. A novel method for genotyping the Helicobacter pylori vacA intermediate region directly in gastric biopsy specimens. J. Clin. Microbiol. 2012, 50, 3983-3989. [CrossRef] [PubMed]

2. Memon, A.A.; Hussein, N.R.; Miendje Deyi, V.Y.; Burette, A.; Atherton, J.C. Vacuolating cytotoxin genotypes are strong markers of gastric cancer and duodenal ulcer-associated Helicobacter pylori strains: A matched case-control study. J. Clin. Microbiol. 2014, 52, 2984-2989. [CrossRef] [PubMed]

3. Shimoyama, T.; Yoshimura, T.; Mikami, T.; Fukuda, S.; Crabtree, J.E.; Munakata, A. Evaluation of Helicobacter pylori vacA genotype in Japanese patients with gastric cancer. J. Clin. Pathol. 1998, 51, $299-301$. [CrossRef] [PubMed]

4. Cover, T.L.; Tummuru, M.K.; Cao, P.; Thompson, S.A.; Blaser, M.J. Divergence of genetic sequences for the vacuolating cytotoxin among Helicobacter pylori strains. J. Biol. Chem. 1994, 269, 10566-10573. [PubMed] 
5. Atherton, J.C.; Cao, P.; Peek, R.M., Jr.; Tummuru, M.K.; Blaser, M.J.; Cover, T.L. Mosaicism in vacuolating cytotoxin alleles of Helicobacter pylori. Association of specific vacA types with cytotoxin production and peptic ulceration. J. Biol. Chem. 1995, 270, 17771-17777. [PubMed]

6. Forsyth, M.H.; Atherton, J.C.; Blaser, M.J.; Cover, T.L. Heterogeneity in levels of vacuolating cytotoxin gene (vacA) transcription among Helicobacter pylori strains. Infect. Immun. 1998, 66, 3088-3094. [PubMed]

7. Letley, D.P.; Atherton, J.C. Natural diversity in the $\mathrm{n}$ terminus of the mature vacuolating cytotoxin of Helicobacter pylori determines cytotoxin activity. J. Bacteriol. 2000, 182, 3278-3280. [CrossRef] [PubMed]

8. Strobel, S.; Bereswill, S.; Balig, P.; Allgaier, P.; Sonntag, H.G.; Kist, M. Identification and analysis of a new vacA genotype variant of Helicobacter pylori in different patient groups in germany. J. Clin. Microbiol. 1998, 36, 1285-1289. [PubMed]

9. Van Doorn, L.J.; Figueiredo, C.; Sanna, R.; Pena, S.; Midolo, P.; Ng, E.K.; Atherton, J.C.; Blaser, M.J.; Quint, W.G. Expanding allelic diversity of Helicobacter pylori vacA. J. Clin. Microbiol. 1998, 36, 2597-2603. [PubMed]

10. Rhead, J.L.; Letley, D.P.; Mohammadi, M.; Hussein, N.; Mohagheghi, M.A.; Eshagh Hosseini, M.; Atherton, J.C. A new Helicobacter pylori vacuolating cytotoxin determinant, the intermediate region, is associated with gastric cancer. Gastroenterology 2007, 133, 926-936. [CrossRef] [PubMed]

11. Chung, C.; Olivares, A.; Torres, E.; Yilmaz, O.; Cohen, H.; Perez-Perez, G. Diversity of vacA intermediate region among Helicobacter pylori strains from several regions of the world. J. Clin. Microbiol. 2010, 48, 690-696. [CrossRef] [PubMed]

12. Torres, V.J.; Ivie, S.E.; McClain, M.S.; Cover, T.L. Functional properties of the p33 and p55 domains of the Helicobacter pylori vacuolating cytotoxin. J. Biol. Chem. 2005, 280, 21107-21114. [CrossRef] [PubMed]

13. Sugimoto, M.; Yamaoka, Y. The association of vacA genotype and Helicobacter pylori-related disease in Latin American and African populations. Clin. Microbiol. Infect. 2009, 15, 835-842. [CrossRef] [PubMed]

14. Sugimoto, M.; Zali, M.R.; Yamaoka, Y. The association of vacA genotypes and Helicobacter pylori-related gastroduodenal diseases in the middle east. Eur. J. Clin. Microbiol. Infect. Dis. 2009, 28, 1227-1236. [CrossRef] [PubMed]

15. Kim, I.J.; Blanke, S.R. Remodeling the host environment: Modulation of the gastric epithelium by the Helicobacter pylori vacuolating toxin (vacA). Front. Cell. Infect. Microbiol. 2012, 2. [CrossRef] [PubMed]

16. Basso, D.; Zambon, C.F.; Letley, D.P.; Stranges, A.; Marchet, A.; Rhead, J.L.; Schiavon, S.; Guariso, G.; Ceroti, M.; Nitti, D.; et al. Clinical relevance of Helicobacter pylori cagA and vacA gene polymorphisms. Gastroenterology 2008, 135, 91-99. [CrossRef] [PubMed]

17. Atherton, J.C.; Sharp, P.M.; Cover, T.L.; Gonzalez-Valencia, G.; Peek, R.M., Jr.; Thompson, S.A.; Hawkey, C.J.; Blaser, M.J. Vacuolating cytotoxin (vacA) alleles of Helicobacter pylori comprise two geographically widespread types, $\mathrm{m} 1$ and $\mathrm{m} 2$, and have evolved through limited recombination. Curr. Microbiol. 1999, 39, 211-218. [CrossRef] [PubMed]

18. Pagliaccia, C.; de Bernard, M.; Lupetti, P.; Ji, X.; Burroni, D.; Cover, T.L.; Papini, E.; Rappuoli, R.; Telford, J.L.; Reyrat, J.M. The $\mathrm{m} 2$ form of the Helicobacter pylori cytotoxin has cell type-specific vacuolating activity. Proc. Natl. Acad. Sci. USA 1998, 95, 10212-10217. [CrossRef] [PubMed]

19. Ji, X.; Fernandez, T.; Burroni, D.; Pagliaccia, C.; Atherton, J.C.; Reyrat, J.M.; Rappuoli, R.; Telford, J.L. Cell specificity of Helicobacter pylori cytotoxin is determined by a short region in the polymorphic midregion. Infect. Immun. 2000, 68, 3754-3757. [CrossRef] [PubMed]

20. Ogiwara, H.; Sugimoto, M.; Ohno, T.; Vilaichone, R.K.; Mahachai, V.; Graham, D.Y.; Yamaoka, Y. Role of deletion located between the intermediate and middle regions of the Helicobacter pylori vacA gene in cases of gastroduodenal diseases. J. Clin. Microbiol. 2009, 47, 3493-3500. [CrossRef] [PubMed]

21. Bakhti, S.Z.; Latifi-Navid, S.; Mohammadi, S.; Zahri, S.; Bakhti, F.S.; Feizi, F.; Yazdanbod, A.; Siavoshi, F. Relevance of Helicobacter pylori vacA $3^{\prime}$-end region polymorphism to gastric cancer. Helicobacter 2015. [CrossRef] [PubMed]

22. Papini, E.; de Bernard, M.; Milia, E.; Bugnoli, M.; Zerial, M.; Rappuoli, R.; Montecucco, C. Cellular vacuoles induced by Helicobacter pylori originate from late endosomal compartments. Proc. Natl. Acad. Sci. USA 1994, 91, 9720-9724. [CrossRef] [PubMed]

23. Cover, T.L.; Blanke, S.R. Helicobacter pylori vacA, a paradigm for toxin multifunctionality. Nat. Rev. Microbiol. 2005, 3, 320-332. [CrossRef] [PubMed] 
24. Molinari, M.; Salio, M.; Galli, C.; Norais, N.; Rappuoli, R.; Lanzavecchia, A.; Montecucco, C. Selective inhibition of Ii-dependent antigen presentation by Helicobacter pylori toxin vacA. J. Exp. Med. 1998, 187, 135-140. [CrossRef] [PubMed]

25. Zheng, P.Y.; Jones, N.L. Helicobacter pylori strains expressing the vacuolating cytotoxin interrupt phagosome maturation in macrophages by recruiting and retaining taco (coronin 1) protein. Cell Microbiol. 2003, 5, $25-40$. [CrossRef] [PubMed]

26. Li, Y.; Wandinger-Ness, A.; Goldenring, J.R.; Cover, T.L. Clustering and redistribution of late endocytic compartments in response to Helicobacter pylori vacuolating toxin. Mol. Biol. Cell 2004, 15, 1946-1959. [CrossRef] [PubMed]

27. McClain, M.S.; Cao, P.; Iwamoto, H.; Vinion-Dubiel, A.D.; Szabo, G.; Shao, Z.; Cover, T.L. A 12-amino-acid segment, present in type s2 but not type s1 Helicobacter pylori VacA proteins, abolishes cytotoxin activity and alters membrane channel formation. J. Bacteriol. 2001, 183, 6499-6508. [CrossRef] [PubMed]

28. Wang, W.C.; Wang, H.J.; Kuo, C.H. Two distinctive cell binding patterns by vacuolating toxin fused with glutathione s-transferase: One high-affinity m1-specific binding and the other lower-affinity binding for variant $\mathrm{m}$ forms. Biochemistry 2001, 40, 11887-11896. [CrossRef] [PubMed]

29. Letley, D.P.; Rhead, J.L.; Twells, R.J.; Dove, B.; Atherton, J.C. Determinants of non-toxicity in the gastric pathogen Helicobacter pylori. J. Biol. Chem. 2003, 278, 26734-26741. [CrossRef] [PubMed]

30. Atherton, J.C.; Peek, R.M., Jr.; Tham, K.T.; Cover, T.L.; Blaser, M.J. Clinical and pathological importance of heterogeneity in vacA, the vacuolating cytotoxin gene of Helicobacter pylori. Gastroenterology 1997, 112, 92-99. [CrossRef]

31. Ferreira, R.M.; Machado, J.C.; Figueiredo, C. Clinical relevance of Helicobacter pylori vacA and cagA genotypes in gastric carcinoma. Best Pract. Res. Clin. Gastroenterol. 2014, 28, 1003-1015. [CrossRef] [PubMed]

32. Salama, N.R.; Otto, G.; Tompkins, L.; Falkow, S. Vacuolating cytotoxin of Helicobacter pylori plays a role during colonization in a mouse model of infection. Infect. Immun. 2001, 69, 730-736. [CrossRef] [PubMed]

33. Ayraud, S.; Janvier, B.; Fauchere, J.L. Experimental colonization of mice by fresh clinical isolates of Helicobacter pylori is not influenced by the cagA status and the vacA genotype. FEMS Immunol. Med. Microbiol. 2002, 34, 169-172. [CrossRef] [PubMed]

34. Winter, J.A.; Letley, D.P.; Cook, K.W.; Rhead, J.L.; Zaitoun, A.A.; Ingram, R.J.; Amilon, K.R.; Croxall, N.J.; Kaye, P.V.; Robinson, K.; et al. A role for the vacuolating cytotoxin, vacA, in colonization and Helicobacter pylori-induced metaplasia in the stomach. J. Infect. Dis. 2014, 210, 954-963. [CrossRef] [PubMed]

35. Rasheed, F.; Campbell, B.J.; Alfizah, H.; Varro, A.; Zahra, R.; Yamaoka, Y.; Pritchard, D.M. Analysis of clinical isolates of Helicobacter pylori in pakistan reveals high degrees of pathogenicity and high frequencies of antibiotic resistance. Helicobacter 2014, 19, 387-399. [CrossRef] [PubMed]

36. Rahimian, G.; Sanei, M.H.; Shirzad, H.; Azadegan-Dehkordi, F.; Taghikhani, A.; Salimzadeh, L.; Hashemzadeh-Chaleshtori, M.; Rafieian-Kopaei, M.; Bagheri, N. Virulence factors of Helicobacter pylori VacA increase markedly gastric mucosal TFG- $\beta 1$-beta1 mRNA expression in gastritis patients. Microb. Pathog. 2014, 67-68, 1-7. [CrossRef] [PubMed]

37. Neu, B.; Rad, R.; Reindl, W.; Neuhofer, M.; Gerhard, M.; Schepp, W.; Prinz, C. Expression of tumor necrosis factor- $\alpha$-related apoptosis-inducing ligand and its proapoptotic receptors is down-regulated during gastric infection with virulent $c a g A+/ v a c A s 1+$ Helicobacter pylori strains. J. Infect. Dis. 2005, 191, 571-578. [CrossRef] [PubMed]

38. Toller, I.M.; Neelsen, K.J.; Steger, M.; Hartung, M.L.; Hottiger, M.O.; Stucki, M.; Kalali, B.; Gerhard, M.; Sartori, A.A.; Lopes, M.; et al. Carcinogenic bacterial pathogen Helicobacter pylori triggers DNA double-strand breaks and a DNA damage response in its host cells. Proc. Natl. Acad. Sci. USA 2011, 108, 14944-14949. [CrossRef] [PubMed]

39. Nogueira, C.; Figueiredo, C.; Carneiro, F.; Gomes, A.T.; Barreira, R.; Figueira, P.; Salgado, C.; Belo, L.; Peixoto, A.; Bravo, J.C.; et al. Helicobacter pylori genotypes may determine gastric histopathology. Am. J. Pathol. 2001, 158, 647-654. [CrossRef]

40. Correa, P. Human gastric carcinogenesis: A multistep and multifactorial process—First American cancer society award lecture on cancer epidemiology and prevention. Cancer Res. 1992, 52, 6735-6740. [PubMed]

41. Jones, N.L.; Day, A.S.; Jennings, H.; Shannon, P.T.; Galindo-Mata, E.; Sherman, P.M. Enhanced disease severity in Helicobacter pylori-infected mice deficient in fas signaling. Infect. Immun. 2002, 70, 2591-2597. [CrossRef] [PubMed] 
42. Peek, R.M., Jr.; Wirth, H.P.; Moss, S.F.; Yang, M.; Abdalla, A.M.; Tham, K.T.; Zhang, T.; Tang, L.H.; Modlin, I.M.; Blaser, M.J. Helicobacter pylori alters gastric epithelial cell cycle events and gastrin secretion in mongolian gerbils. Gastroenterology 2000, 118, 48-59. [CrossRef]

43. Fan, X.; Crowe, S.E.; Behar, S.; Gunasena, H.; Ye, G.; Haeberle, H.; Van Houten, N.; Gourley, W.K.; Ernst, P.B.; Reyes, V.E. The effect of class II major histocompatibility complex expression on adherence of Helicobacter pylori and induction of apoptosis in gastric epithelial cells: A mechanism for T helper cell type 1-mediated damage. J. Exp. Med. 1998, 187, 1659-1669. [CrossRef] [PubMed]

44. Cover, T.L.; Blaser, M.J. Helicobacter pylori in health and disease. Gastroenterology 2009, 136, $1863-1873$. [CrossRef] [PubMed]

45. Jang, S.; Jones, K.R.; Olsen, C.H.; Joo, Y.M.; Yoo, Y.J.; Chung, I.S.; Cha, J.H.; Merrell, D.S. Epidemiological link between gastric disease and polymorphisms in vacA and cagA. J. Clin. Microbiol. 2010, 48, 559-567. [CrossRef] [PubMed]

46. Yamaoka, Y.; Kato, M.; Asaka, M. Geographic differences in gastric cancer incidence can be explained by differences between Helicobacter pylori strains. Intern. Med. 2008, 47, 1077-1083. [CrossRef] [PubMed]

47. Zambon, C.F.; Navaglia, F.; Basso, D.; Rugge, M.; Plebani, M. Helicobacter pylori babA2, cagA, and s1 vacA genes work synergistically in causing intestinal metaplasia. J. Clin. Pathol. 2003, 56, 287-291. [CrossRef] [PubMed]

48. Gunn, M.C.; Stephens, J.C.; Stewart, J.A.; Rathbone, B.J.; West, K.P. The significance of $\operatorname{cag} A$ and $v a c A$ subtypes of Helicobacter pylori in the pathogenesis of inflammation and peptic ulceration. J. Clin. Pathol. 1998, 51, 761-764. [CrossRef] [PubMed]

49. Soltermann, A.; Koetzer, S.; Eigenmann, F.; Komminoth, P. Correlation of Helicobacter pylori virulence genotypes vacA and $\operatorname{cag} A$ with histological parameters of gastritis and patient's age. Mod. Pathol. 2007, 20, 878-883. [CrossRef] [PubMed]

50. Siddique, I.; Al-Qabandi, A.; Al-Ali, J.; Alazmi, W.; Memon, A.; Mustafa, A.S.; Junaid, T.A. Association between Helicobacter pylori genotypes and severity of chronic gastritis, peptic ulcer disease and gastric mucosal interleukin-8 levels: Evidence from a study in the Middle East. Gut Pathog. 2014, 6, 41. [CrossRef] [PubMed]

51. Trang, T.T.; Shiota, S.; Matsuda, M.; Binh, T.T.; Suzuki, R.; Vilaichone, R.K.; Mahachai, V.; Tshering, L.; Dung, H.D.; Uchida, T.; et al. The prevalence of Helicobacter pylori virulence factors in Bhutan, Vietnam, and Myanmar is related to gastric cancer incidence. Biomed. Res. Int. 2015, 2015, 830813. [CrossRef] [PubMed]

52. Gonzalez, C.A.; Figueiredo, C.; Lic, C.B.; Ferreira, R.M.; Pardo, M.L.; Ruiz Liso, J.M.; Alonso, P.; Sala, N.; Capella, G.; Sanz-Anquela, J.M. Helicobacter pylori cagA and vacA genotypes as predictors of progression of gastric preneoplastic lesions: A long-term follow-up in a high-risk area in Spain. Am. J. Gastroenterol. 2011, 106, 867-874. [CrossRef] [PubMed]

53. Ferreira, R.M.; Figueiredo, C.; Bonet, C.; Pardo, M.L.; Liso, J.M.; Alonso, P.; Sala, N.; Capella, G.; Sanz-Anquela, J.M.; Gonzalez, C.A. Helicobacter pylori vacA intermediate region genotyping and progression of gastric preneoplastic lesions. Am. J. Gastroenterol. 2012, 107, 145-146. [CrossRef] [PubMed]

54. Figura, N.; Valassina, M.; Moretti, E.; Vindigni, C.; Collodel, G.; Iacoponi, F.; Giordano, N.; Roviello, F.; Marrelli, D. Histological variety of gastric carcinoma and Helicobacter pylori cagA and vacA polymorphism. Eur. J. Gastroenterol. Hepatol. 2015, 27, 1017-1021. [PubMed]

55. Biernat, M.M.; Gosciniak, G.; Iwanczak, B. Prevalence of Helicobacter pylori cagA, vacA, iceA, babA2 genotypes in polish children and adolescents with gastroduodenal disease. Postepy Hig. Med. Doswiadczalnej (Online) 2014, 68, 1015-1021. [CrossRef] [PubMed]

56. Almeida, N.; Donato, M.M.; Romaozinho, J.M.; Luxo, C.; Cardoso, O.; Cipriano, M.A.; Marinho, C.; Fernandes, A.; Sofia, C. Correlation of Helicobacter pylori genotypes with gastric histopathology in the central region of a South-European country. Dig. Dis. Sci. 2015, 60, 74-85. [CrossRef] [PubMed]

57. Wang, F.; Wu, X.; Liu, Z.; Bu, G.; Li, X.; Qu, N.; Peng, J.; Xu, C.; Shen, S.; Yuan, Y. Association between virulence factors and TRAF1/4-1BB/Bcl-xL expression in gastric mucosa infected with Helicobacter pylori. Gastroenterol. Res. Pract. 2015, 2015, 648479. [CrossRef] [PubMed]

58. Breurec, S.; Michel, R.; Seck, A.; Brisse, S.; Come, D.; Dieye, F.B.; Garin, B.; Huerre, M.; Mbengue, M.; Fall, C.; et al. Clinical relevance of $\operatorname{cag} A$ and vacA gene polymorphisms in Helicobacter pylori isolates from senegalese patients. Clin. Microbiol. Infect. 2012, 18, 153-159. [CrossRef] [PubMed] 
59. Ogiwara, H.; Graham, D.Y.; Yamaoka, Y. vacA i-region subtyping. Gastroenterology 2008, 134, 1267. [CrossRef] [PubMed]

60. Yordanov, D.; Boyanova, L.; Markovska, R.; Gergova, G.; Mitov, I. Significance of Helicobacter pylori vacA intermediate region genotyping-a Bulgarian study. Diagn. Microbiol. Infect. Dis. 2012, 74, 253-257. [CrossRef] [PubMed]

61. Mottaghi, B.; Safaralizadeh, R.; Bonyadi, M.; Latifi-Navid, S.; Somi, M.H. Helicobacter pylori vacA i region polymorphism but not babA2 status associated to gastric cancer risk in Northwestern Iran. Clin. Exp. Med. 2014, 16, 57-63. [CrossRef] [PubMed]

62. Gonzalez-Rivera, C.; Algood, H.M.; Radin, J.N.; McClain, M.S.; Cover, T.L. The intermediate region of Helicobacter pylori vacA is a determinant of toxin potency in a jurkat $\mathrm{T}$ cell assay. Infect. Immun. 2012, 80, 2578-2588. [CrossRef] [PubMed]

63. Basiri, Z.; Safaralizadeh, R.; Bonyadi, M.J.; Somi, M.H.; Mahdavi, M.; Latifi-Navid, S. Helicobacter pylori vacA d1 genotype predicts risk of gastric adenocarcinoma and peptic ulcers in Northwestern Iran. Asian Pac. J. Cancer Prev. 2014, 15, 1575-1579. [CrossRef] [PubMed]

64. Latifi-Navid, S.; Mohammadi, S.; Maleki, P.; Zahri, S.; Yazdanbod, A.; Siavoshi, F.; Massarrat, S. Helicobacter pylori vacA d1/-i1 genotypes and geographic differentiation between high and low incidence areas of gastric cancer in Iran. Arch. Iran. Med. 2013, 16, 330-337. [PubMed]

65. Ladeira, M.S.; Bueno, R.C.; Dos Santos, B.F.; Pinto, C.L.; Prado, R.P.; Silveira, M.G.; Rodrigues, M.A.; Bartchewsky, W., Jr.; Pedrazzoli, J., Jr.; Ribeiro, M.L.; et al. Relationship among oxidative DNA damage, gastric mucosal density and the relevance of $c a g A, v a c A$ and iceA genotypes of Helicobacter pylori. Dig. Dis. Sci. 2008, 53, 248-255. [CrossRef] [PubMed]

66. Sze, M.A.; Chen, Y.W.; Tam, S.; Tashkin, D.; Wise, R.A.; Connett, J.E.; Man, S.P.; Sin, D.D. The relationship between Helicobacter pylori seropositivity and COPD. Thorax 2015. [CrossRef] [PubMed]

67. Kraus, J.; Nartova, E.; Pavlik, E.; Katra, R.; Sterzl, I.; Astl, J. Prevalence of Helicobacter pylori in adenotonsillar hypertrophy in children. Acta Oto-Laryngol. 2014, 134, 88-92. [CrossRef] [PubMed]

68. Nakashima, S.; Kakugawa, T.; Yura, H.; Tomonaga, M.; Harada, T.; Hara, A.; Hara, S.; Nakano, M.; Yamasaki, E.; Sakamoto, N.; et al. Identification of Helicobacter pylori vacA in human lung and its effects on lung cells. Biochem. Biophys. Res. Commun. 2015, 460, 721-726. [CrossRef] [PubMed]

69. Santibanez, M.; Aguirre, E.; Belda, S.; Aragones, N.; Saez, J.; Rodriguez, J.C.; Galiana, A.; Sola-Vera, J.; Ruiz-Garcia, M.; Paz-Zulueta, M.; et al. Relationship between tobacco, cag $A$ and $v a c A$ i1 virulence factors and bacterial load in patients infected by Helicobacter pylori. PLoS ONE 2015, 10, e0120444. [CrossRef] [PubMed]

(C) 2016 by the authors; licensee MDPI, Basel, Switzerland. This article is an open access article distributed under the terms and conditions of the Creative Commons Attribution (CC-BY) license (http:/ / creativecommons.org/licenses/by/4.0/). 